\title{
Parametric Analysis of a Single Alkaline Membrane Fuel Cell
}

\author{
Lauber S. Martins, ${ }^{1}$ Elise M. Sommer, ${ }^{2}$ Jose V. C. Vargas, ${ }^{3}$ Juan C. Ordonez ${ }^{4}$ and Josua P. Meyer ${ }^{1}$
}

\author{
${ }^{1}$ Department of Mechanical and Aeronautical Engineering, University of Pretoria, Pretoria, South Africa ${ }^{2}$ Departamento de Engenharia de \\ Energia, Universidade Federal de Santa Catarina, Ararangua, Santa Catarina, Brazil ${ }^{3}$ Departamento de Engenharia Mecanica, Universidade \\ Federal do Parana, Curitiba, Parana, Brazil \\ ${ }^{4}$ Department of Mechanical Engineering and Center for Advanced Power Systems, Florida State University, Tallahassee, Florida, USA
}

\begin{abstract}
When geometric parameters, such as volume and thickness, are constraints to be considered in real applications and an increase of performance is required, other parameters must be taken into account for the optimization of fuel cells. The physical properties of bipolar plates, electrodes, and membranes are some of the parameters that can still be studied when maximum power output is sought under geometric constraint. This paper investigated the influence of porosity of the diffusive and reaction layers on the power output of an alkaline membrane fuel cell (AMFC). An experimentally validated mathematical model was used to simulate the fuel cell performance as a function of different porosities of the electrode. It was found that the change of porosity of the diffusive layer has a minimum influence in the power output of the fuel cell when the porosity of the reaction layer is kept constant. The cathode was shown to limit the performance of the fuel cell due to losses that make the polarization curve to drop to zero at the cathode faster than at the anode. The increase of the porosity of the reaction layer is verified to be an alternative to enhance the power output of the fuel cell.
\end{abstract}

\section{Introduction}

The alkaline membrane fuel cell (AMFC) is a recently developed fuel cell type that has shown good experimental results in the laboratory. Alkaline fuel cells are seen as an alternative for polymer electrolyte membrane fuel cell (PEMFC) applications due to the possibility of not using noble metals as catalyst, which could be a good alternative when cost is considered an important issue. Alkaline membrane fuel cells have a special differential: The membrane is made out of a solid and porous support soaked on a potassium hydroxide solution. Because of the membrane, this new type of fuel cell was named the alkaline membrane fuel cell, or AMFC.

The main advantage of using alkaline fuel cells comes from the fact that the kinetics of the electrochemical reactions are faster in alkaline than in acid medium [1-4], which grants the possibility of using non-noble metals as catalyst without compromising the performance of the electrochemical reaction $[5,6]$.

Address correspondence to Dr. Lauber Martins, Department of Mechanical and Aeronautical Engineering, University of Pretoria, Private Bag X20, Hatfield, Pretoria 0028, South Africa. E-mail: lauber.martins@up.ac.za
Scientists around the world have spent resources on investigating a new material for the electrode and membrane aimed at less transport losses [3, 7-18]. Resources have also been spent on modeling, simulation, and optimization of alkaline fuel cells under specific constraints [19-23]. A good combination of research on the finding of new material and the advances of modeling and optimization is the goal to be achieved for a successful application in the manufacturing of new devices and appliances with fuel cells.

When geometry (internal structure) is a restriction for an optimization analysis for an operating fuel cell, only physical properties of the materials can be changed when pursuing an increase of power output. This paper presents a steady-state analysis of an operating prototype of an alkaline membrane fuel cell. The objective is to investigate the influence of the porosity of the electrodes (diffusive and reaction layers) in the power output of the fuel cell when the internal structure (length) is kept constant.

\section{Thermodynamic Model}

With the intent to emphasize its main features and highlight the assumptions and the understanding of the phenomena, the 


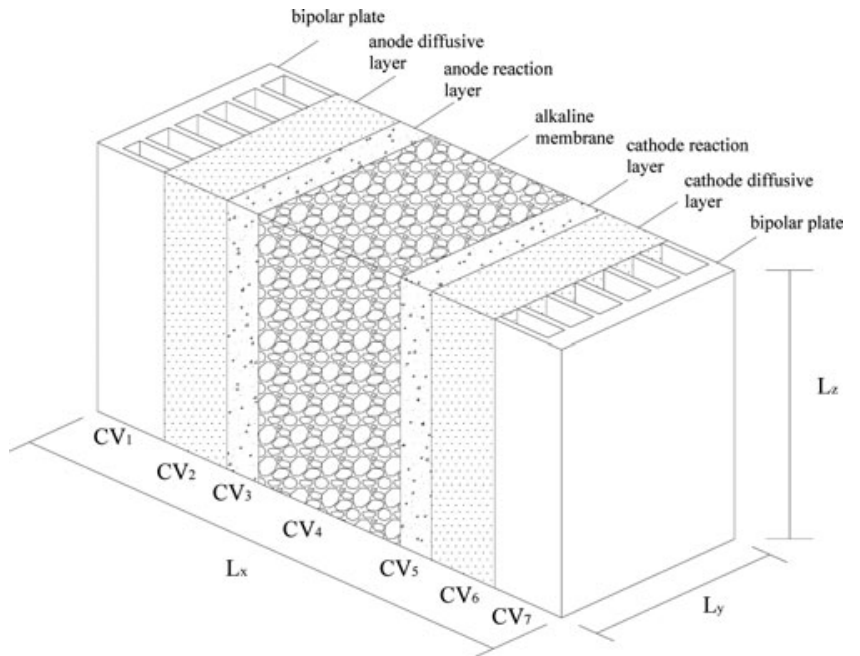

Figure 1 Schematic diagram of the internal structure of a single AMFC.

mathematical model of a single AMFC used for the present study, which was introduced and validated in previous studies $[20,22]$, is herein summarized. The previous work was applied in the present study as a tool for parametric analysis of a single AMFC and used to simulate the fuel cell performance as a function of different porosities of the electrode diffusive and reaction layers.

The fuel and the oxidant considered in this study were pure hydrogen and pure oxygen, respectively. Metal bipolar plates were included to provide a medium through which the electrons produced at the anode could flow to the external circuit or to the next fuel cell. The internal parts of the fuel cell were split into seven control volumes. The seven internal part transfer energy and/or mass to each other and to the ambient. A schematic diagram of the internal structure of an AMFC is shown in Figures 1 and 2.

Conservations equations were applied to each control volume, also accounting for the electrochemical reactions at the cathode and the anode. Temperature and pressure at the control volumes were considered to evaluate the reversible electrical potential and power of the fuel cell.

Activation, concentration, and ohmic overpotential losses were computed to obtain the actual electrical potential and power output of the fuel cell. The electrical current (I) was considered an independent variable; that is, all the overpotential losses and temperatures were modeled as function of the current

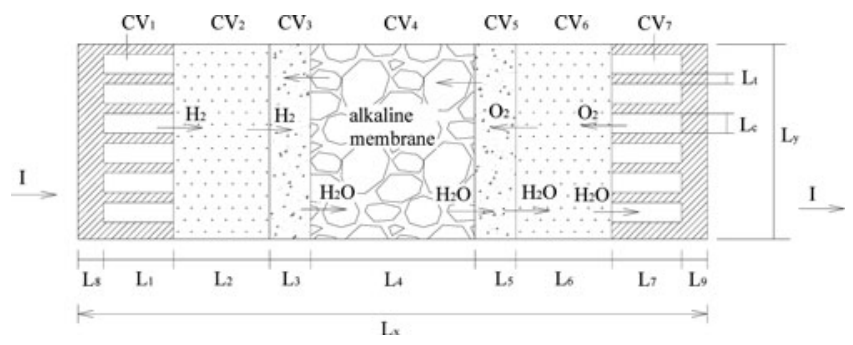

Figure 2 Top view of the internal structure of a single AMFC. generated (I), which in real applications is determined by the external load.

The control volumes (CV) are fuel channel (CV1), the anode diffusive layer (CV2), the anode reaction layer (CV3), the membrane (CV4), the cathode reaction layer (CV5), the cathode diffusion backing layer (CV6), and the oxidant channel (CV7).

Dimensionless variables are defined based on the geometric and operating parameters of the system. Pressures and temperatures are referenced to ambient conditions: $\mathrm{P}_{\mathrm{i}}=\mathrm{p}_{\mathrm{i}} / \mathrm{p}_{\infty}$ and $\theta_{i}=T_{i} / T_{\infty}$, where $\mathrm{p}_{\infty}$ and $\mathrm{T}_{\infty}$ are the ambient pressure and ambient temperature, respectively. The dimensionless mass flow rates, $\psi$, the dimensionless global wall heat transfer coefficient, $\mathrm{N}$, and the dimensionless area, $\tilde{A}$, are defined as

$$
\psi=\frac{\dot{\mathrm{m}}_{\mathrm{i}}}{\dot{\mathrm{m}}_{\mathrm{ref}}}
$$

$$
\mathrm{N}_{i}=\frac{\mathrm{U}_{\mathrm{wi}} \mathrm{V}_{\mathrm{T}}^{2 / 3}}{\dot{\mathrm{m}}_{\mathrm{ref}} \mathrm{c}_{\mathrm{p}, \mathrm{f}}}, \tilde{\mathrm{A}}_{\mathrm{i}}=\frac{\mathrm{A}_{\mathrm{i}}}{\mathrm{V}_{\mathrm{T}}^{2 / 3}}
$$

where the subscript $i$ indicates a location in the fuel cell, $c_{p}$ is the specific heat at constant pressure, $V_{\mathrm{T}}$ is the total volume of the fuel cell, and $\dot{\mathrm{m}}_{\mathrm{ref}}=5 \times 10^{-4} \mathrm{kgs}^{-1}$ is the reference mass flow rate.

The fixed length scale, $\mathrm{V}_{\mathrm{T}}^{1 / 3}$, is used for the purpose of non$\backslash$ dimensionalizing all the lengths that characterize the fuel cell geometry,

$$
\xi_{j}=\frac{\mathrm{L}_{\mathrm{j}}}{\mathrm{V}_{\mathrm{T}}^{1 / 3}}
$$

where the subscript $\mathrm{j}$ indicates a particular dimension of the fuel cell geometry, as in Figure 1.

Additional dimensionless variables are

$$
\tilde{\mathrm{h}}_{\mathrm{i}}=\frac{\mathrm{h}_{\mathrm{i}} \mathrm{V}_{\mathrm{T}}^{2 / 3}}{\dot{\mathrm{m}}_{\mathrm{ref}} \mathrm{c}_{\mathrm{p}, \mathrm{f}}}, \tilde{\mathrm{k}}_{\mathrm{n}}=\frac{\mathrm{k}_{\mathrm{n}} \mathrm{V}_{\mathrm{T}}^{1 / 3}}{\dot{\mathrm{m}}_{\mathrm{ref}} \mathrm{c}_{\mathrm{p}, \mathrm{f}}}
$$

where the subscript $i$ indicates a location and the subscript $n$ indicates a substance in the fuel cell, $\tilde{h}$ is the dimensionless heat transfer coefficient, and $\tilde{\mathrm{k}}$ is the dimensionless thermal conductivity.

The hydrogen mass flow rate required for the current (I) dictated by the external load is

$$
\dot{\mathrm{m}}_{\mathrm{H}_{2}}=\dot{\mathrm{n}}_{\mathrm{H}_{2}} \mathrm{M}_{\mathrm{H}_{2}}=\frac{\mathrm{I}}{\mathrm{nF}} \mathrm{M}_{\mathrm{H}_{2}}
$$

Therefore, the oxygen mass flow rate needed for an AMFC fuel cell is

$$
\dot{\mathrm{m}}_{\mathrm{O}_{2}}=\frac{1}{2} \dot{\mathrm{n}}_{\mathrm{H}_{2}} \mathrm{M}_{\mathrm{O}_{2}}
$$

where $\dot{n}$ is the molar flow rate, $\mathrm{M}$ the molar weight, $n$ the number of moles of electrons formed in the reaction, and $\mathrm{F}$ the Faraday constant 96,5600 C/eq.

Stoichiometric ratios, $\zeta$, greater than 1 are prescribed on the fuel side, $\zeta_{1}$, and oxidant side, $\zeta_{7}$. 
The wall heat transfer area of one control volume is $\mathrm{A}_{w i}=$ $\tilde{p}_{s} \mathrm{~L}_{\mathrm{i}}(2 \leq \mathrm{i} \leq 6)$ and $\mathrm{A}_{\mathrm{wi}} \cong \tilde{p}_{s} \mathrm{~L}_{\mathrm{i}}+\mathrm{L}_{\mathrm{y}} \mathrm{L}_{\mathrm{z}}(\mathrm{i}=1,7)$, where $\tilde{p}_{s}=$ $2\left(\mathrm{~L}_{\mathrm{y}}+\mathrm{L}_{\mathrm{z}}\right)$ is the perimeter of the fuel cell cross-section. The control volumes are $\mathrm{V}_{\mathrm{j}}=\mathrm{L}_{\mathrm{y}} \mathrm{L}_{\mathrm{z}} \mathrm{L}_{\mathrm{j}}(2 \leq \mathrm{j} \leq 6)$ and $\mathrm{V}_{\mathrm{j}}=\mathrm{n}_{\mathrm{c}} \mathrm{L}_{\mathrm{c}}$ $\mathrm{L}_{\mathrm{j}} \mathrm{L}_{\mathrm{z}}(\mathrm{j}=1,7)$, where $\mathrm{n}_{\mathrm{c}}$ is the integer part of $\mathrm{L}_{\mathrm{y}} /\left(\mathrm{L}_{\mathrm{t}}+\mathrm{L}_{\mathrm{c}}\right)$, that is, the number of parallel ducts in each gas channel (fuel and oxidant).

The energy balances for CV1 yield the temperature in CV1,

$$
\mathrm{Q}_{\mathrm{w} 1}+\psi_{\mathrm{f}}\left(\theta_{\mathrm{f}}-\theta_{1}\right)+\tilde{\mathrm{Q}}_{12}+\tilde{\mathrm{Q}}_{1 \mathrm{ohm}}=0
$$

where $\tilde{\mathrm{Q}}_{\mathrm{w} 1}=\mathrm{N} \tilde{\mathrm{A}}_{\mathrm{w} 1}\left(1-\theta_{1}\right), \tilde{\mathrm{Q}}_{12}=\tilde{\mathrm{h}}_{1} \tilde{\mathrm{A}}_{\mathrm{s}}\left(1-\phi_{2}\right)\left(\theta_{2}-\theta_{1}\right)$, and $\tilde{\mathrm{A}}_{\mathrm{s}}=\mathrm{L}_{\mathrm{y}} \mathrm{L}_{\mathrm{z}} / \mathrm{V}_{\mathrm{T}}^{2 / 3}$. The dimensionless heat transfer rates for all the compartments are $\tilde{Q}_{i}=Q_{i} / \dot{\mathrm{m}}_{\mathrm{ref}} \mathrm{c}_{\mathrm{p}, \mathrm{f}} \mathrm{T}_{\infty}$, where $\mathrm{i}$ accounts for any of the heat transfer interactions that are present in the model. The ohmic heating is $\tilde{\mathrm{Q}}_{\mathrm{iohm}}=\mathrm{I}^{2} \beta_{\mathrm{i}} / \dot{\mathrm{m}}_{\mathrm{ref}} \mathrm{c}_{\mathrm{p}, \mathrm{f}} \mathrm{T}_{\infty}$, where the subscript $i$ refers to a control volume $(1-7)$, and $\beta(\Omega)$ is the electrical resistance. The subscript $\mathrm{f}$ indicates fuel, ohm indicates ohmic, $\phi$ the porosity, and $\psi_{\mathrm{f}}=\zeta_{1} \psi_{\mathrm{H}_{2}}$.

Using the ideal gas model and Darcy friction factor, assuming that the channels are straight and sufficiently slender, the pressure drops are

$$
\Delta \mathrm{P}_{\mathrm{i}}=\mathrm{n}_{\mathrm{c}} \mathrm{f}_{\mathrm{i}}\left(\frac{\xi_{\mathrm{z}}}{\xi_{\mathrm{i}}}+\frac{\xi_{\mathrm{z}}}{\xi_{\mathrm{c}}}\right) \frac{\mathrm{P}_{\mathrm{j}}}{\theta_{\mathrm{i}}} \frac{\mathrm{R}_{\mathrm{f}}}{\mathrm{R}_{\mathrm{j}}} \tilde{\mathrm{u}}_{\mathrm{i}}^{2}
$$

where $\mathrm{n}_{\mathrm{c}}$ is the number of ducts in the gas channel, the subscript $\mathrm{i}=1,7$ represent the control volume in which the pressure drop is evaluated, and $\mathrm{j}=\mathrm{f}$, ox, represents the fuel (hydrogen) and oxidant (oxygen), respectively. Here $\tilde{\mathrm{u}}_{i}=\left(\tilde{\mathrm{u}}_{\mathrm{i} \text {,in }}+\tilde{\mathrm{u}}_{\mathrm{i} \text {,out }}\right) / 2$ is the channel dimensionless mean velocity, defined as $\tilde{\mathrm{u}}=$ $\mathrm{u} /\left(\mathrm{R}_{\mathrm{f}} \mathrm{T}_{\infty}\right)^{1 / 2}$, $\mathrm{f}$ is the friction factor, and $\mathrm{R}$ is the ideal gas constant. According to mass conservation, the dimensionless mean velocities in the gas channels are

$$
\begin{aligned}
& \tilde{\mathrm{u}}_{1}=\frac{\mathrm{C} \theta_{1}}{\tilde{\mathrm{A}}_{\mathrm{c} 1} \mathrm{P}_{\mathrm{f}}}\left[\psi_{\mathrm{f}}-\frac{\psi_{\mathrm{H}_{2}}}{2}\right] \\
& \tilde{\mathrm{u}}_{7}=\frac{\mathrm{R}_{\mathrm{ox}} \mathrm{C} \theta_{7}}{\mathrm{R}_{\mathrm{f}} \tilde{\mathrm{A}}_{\mathrm{c} 7} \mathrm{P}_{\mathrm{ox}}}\left[\psi_{\mathrm{ox}}-\frac{\psi_{\mathrm{O}_{2}}}{2}\right]
\end{aligned}
$$

where the constant $\mathrm{C}$ is defined as $\mathrm{C}=$ $\left(\mathrm{R}_{\mathrm{f}} \mathrm{T}_{\infty}\right)^{1 / 2} \dot{\mathrm{m}}_{\mathrm{ref}} /\left(\mathrm{p}_{\infty} \mathrm{V}_{\mathrm{T}}^{2 / 3}\right), \quad \tilde{\mathrm{A}}_{\mathrm{ci}}=\mathrm{n}_{\mathrm{c}} \mathrm{L}_{\mathrm{c}} \mathrm{L}_{\mathrm{i}} / \mathrm{V}_{\mathrm{T}}^{2 / 3}, \quad \mathrm{i}=1,7$, and $\mathrm{L}_{\mathrm{c}}$ is the width of the gas channel.

The Reynolds number is monitored to determine the flow regime and appropriate correlations are used accordingly. For the laminar regime $\left(\operatorname{Re}_{D_{h}}<2300\right)$ [24],

$$
\begin{aligned}
\mathrm{f}_{\mathrm{i}} \operatorname{Re}_{\mathrm{Dh}, \mathrm{j}}= & 24\left(1-1.3553 \delta_{i}+1.9467 \delta_{i}^{2}-1.7012 \delta_{i}^{3}\right. \\
& \left.+0.9564 \delta_{\mathrm{i}}^{4}-0.25371 \delta_{\mathrm{i}}^{5}\right) \\
\frac{\mathrm{h}_{\mathrm{i}} \mathrm{D}_{\mathrm{h}, \mathrm{i}}}{\mathrm{k}_{\mathrm{i}}}= & 7.541\left(1-2.610 \delta_{i}+4.970 \delta_{i}^{2}-5.119 \delta_{i}^{3}\right. \\
& \left.+2.702 \delta_{\mathrm{i}}^{4}-0.548 \delta_{\mathrm{i}}^{5}\right)
\end{aligned}
$$

where $\delta_{\mathrm{i}}=\mathrm{L}_{\mathrm{c}} / \mathrm{L}_{\mathrm{i}}$, for $\mathrm{L}_{\mathrm{c}} \leq \mathrm{L}_{\mathrm{i}}$, and $\delta_{\mathrm{i}}=\mathrm{L}_{\mathrm{i}} / \mathrm{L}_{\mathrm{c}}$, for $\mathrm{L}_{\mathrm{c}}>\mathrm{L}_{\mathrm{i}}$;
$\mathrm{D}_{\mathrm{h}, \mathrm{i}}=2 \mathrm{~L}_{\mathrm{c}} \mathrm{L}_{\mathrm{i}} /\left(\mathrm{L}_{\mathrm{t}}+\mathrm{L}_{\mathrm{c}}\right), \operatorname{Re}_{D h, j}=u_{i} D_{h, i} \rho_{i} / \mu_{i}$, and $\mathrm{i}=1,7$. The correlations used for the turbulent regime were [25]

$$
\begin{aligned}
\mathrm{f}_{\mathrm{i}}= & 0.079 \mathrm{Re}_{\mathrm{Dh}, \mathrm{j}}^{-1 / 4}\left(2300<\operatorname{Re}_{\mathrm{Dh}, \mathrm{j}}<2 \times 10^{4}\right) \\
\frac{\mathrm{h}_{\mathrm{i}} \mathrm{D}_{\mathrm{h}, \mathrm{i}}}{\mathrm{k}_{\mathrm{i}}}= & \frac{\left(\mathrm{f}_{\mathrm{i}} / 2\right)\left(\mathrm{D}_{\mathrm{h}, \mathrm{i}}-10^{3}\right) \mathrm{Pr}_{\mathrm{i}}}{1+12.7\left(\mathrm{f}_{\mathrm{i}} / 2\right)^{1 / 2}\left(\operatorname{Pr}^{2 / 3}-1\right)} \\
& \times\left(2300<\operatorname{Re}_{\mathrm{Dh}, \mathrm{j}}<5 \times 10^{6}\right)
\end{aligned}
$$

where Pr is the gas Prandtl number.

The energy balance delivers the CV2 temperature,

$$
\left(\theta_{1}-\theta_{2}\right)+\frac{\tilde{\mathbf{Q}}_{\mathrm{w} 2}+\tilde{\mathbf{Q}}_{23}+\tilde{\mathbf{Q}}_{2 \mathrm{ohm}}-\tilde{\mathbf{Q}}_{12}}{\psi_{\mathrm{H}_{2}}}=0
$$

where $\tilde{\mathrm{Q}}_{23}=\tilde{\mathrm{k}}_{\mathrm{s}, \mathrm{a}}\left(1-\phi_{2}\right) \tilde{\mathrm{A}}_{\mathrm{s}}\left(\theta_{2}-\theta_{3}\right) /\left[\left(\xi_{2}+\xi_{3}\right) / 2\right]$ and the subscript s,a indicates the solid anode side.

We assume diffusion to be the dominant transport mechanism across the diffusive and reaction layer [26], and the pores are approximated as parallel tubes with an average diameter of the same order as the square root of the porous medium permeability, $\mathrm{K}^{1 / 2}$. Therefore, the wetted area for each porous control volume is $\mathrm{A}_{\mathrm{j} \text {, wet }}=4 \phi_{\mathrm{j}} \mathrm{L}_{\mathrm{j}} \mathrm{K}_{\mathrm{j}}^{-1 / 2} \mathrm{~A}_{\mathrm{s}}$ where $\mathrm{K}_{\mathrm{j}}$ is the permeability. The flow in the electrodes is modeled as Knudsen flow [26]. The fuel and oxidant mass fluxes are given by

$$
\mathrm{j}_{\mathrm{i}}=-\frac{\mathrm{D}_{\mathrm{i}}\left(\rho_{\text {out }, \mathrm{i}}-\rho_{\text {in }, \mathrm{i}}\right)}{\mathrm{L}_{\mathrm{i}}}, \mathrm{i}=2,6
$$

where $D_{i}=B\left\{r_{i}\left[8 \bar{R} T_{i} / \pi M\right]^{1 / 2} \phi_{i}^{q}\right\}$ is the Knudsen diffusion coefficient, $\rho$ is the density, $\bar{R}$ the universal gas constant, $r$ the porous radius, $\phi$ porosity, $q$ tortuosity $[27,28]$, and $\mathrm{B}$ is the correction coefficient. The state for which the diffusion coefficient $D_{i}$ should be evaluated is either state 2 (anode diffusive layer) or state 6 (cathode diffusive layer) for $\mathrm{i}=2,6$, respectively. Therefore, the pressures of hydrogen and oxygen that enter the catalyst layers are

$$
P_{i, \text { out }}=P_{i, \text { in }}-\frac{j_{i} R_{k} T_{\infty} L_{i} \theta_{i}}{D_{i} p_{\infty}}, i=2,6 ; k=f, \text { ox }
$$

where $\mathrm{j}_{2}=\dot{\mathrm{m}}_{\mathrm{H}_{2}} / \mathrm{A}_{3 \text {,wet }}$ and $\mathrm{j}_{6}=\dot{\mathrm{m}}_{\mathrm{O}_{2}} / \mathrm{A}_{5 \text {, wet }}$, and $\mathrm{A}_{3 \text {, wet }}$ and $\mathrm{A}_{5, \text { wet }}$. The average pressures in CV2 and CV6 are estimated as

$$
\mathrm{P}_{\mathrm{i}}=\frac{1}{2}\left(\mathrm{P}_{\mathrm{i}, \text { in }}-\mathrm{P}_{\mathrm{i}, \text { out }}\right), \mathrm{i}=2,6
$$

In the anode reaction layer (CV3), the electrical current is generated by the electrochemical reaction,

$$
\mathrm{H}_{2(\mathrm{~g})}+2 \mathrm{OH}_{(\mathrm{aq})}^{-} \rightarrow 2 \mathrm{H}_{2} \mathrm{O}_{(\mathrm{l})}+2 \mathrm{e}^{-}
$$

The dimensionless enthalpy of formation is defined by $\tilde{\mathrm{H}}_{\mathrm{i}}=$ $\dot{\mathrm{n}}_{\mathrm{i}} \mathrm{H}_{\mathrm{i}} /\left(\dot{\mathrm{m}}_{\mathrm{ref}} \mathrm{c}_{\mathrm{p}, \mathrm{f}} \mathrm{T}_{\infty}\right)$, where the subscript $\mathrm{i}$ refers to a substance. The enthalpy change due to the anode reaction is given by $\Delta \mathrm{H}_{3}=\sum$ products $\left[\mathrm{v}_{\mathrm{i}} \mathrm{H}_{\mathrm{i}}\left(\mathrm{T}_{\mathrm{i}}\right)\right]-\sum_{\text {reactan ts }}\left[\mathrm{v}_{\mathrm{i}} \mathrm{H}_{\mathrm{i}}\left(\mathrm{T}_{\mathrm{i}}\right)\right]$ and $\mathrm{W}_{\mathrm{e} 3}=$ $-\Delta G_{3}$, where $v$ is the reaction stoichiometric coefficient, $H_{i}$ is the molar enthalpy of formation at temperature $T_{i}$ of reactants 
or products of compound $\mathrm{i}, \Delta \mathrm{G}_{3}$ is the $\mathrm{CV} 3$ reaction Gibbs free energy change, and $\mathrm{W}_{\mathrm{e} 3}$ is the maximum (reversible) electrical work generated due to reaction in CV3. The molar enthalpies of formation are obtained from the literature [26-28] at $\mathrm{T}_{2}$ for $\mathrm{H}_{2(\mathrm{~g})}, \mathrm{T}_{4}$ for $\mathrm{OH}_{(\mathrm{aq})}^{-}$, and $\mathrm{T}_{3}$ for $\mathrm{H}_{2} \mathrm{O}_{(\mathrm{l})}$ and at $1 \mathrm{~atm}$, because $\Delta \mathrm{H}$ is independent of pressure.

The reaction Gibbs free energy change, $\Delta G$, is a function of temperature, pressure, and concentrations [29],

$$
\Delta \mathrm{G}=\Delta \mathrm{G}^{0}+\overline{\mathrm{R}} \mathrm{T} \text { In } \mathrm{Q}
$$

where $\Delta \mathrm{G}^{0}=\Delta \mathrm{H}+\mathrm{T} \Delta \mathrm{S}$. Therefore, for the anode reaction [Eq. (19)], the resulting expression for $\mathrm{Q}_{3}$ is $\mathrm{Q}_{3}=\left\{\left[\mathrm{OH}_{(\mathrm{aq})}^{-}\right]^{2} \mathrm{p}_{\mathrm{H}_{2}}\right\}^{-1}$, where $\left[\mathrm{OH}_{(\mathrm{aq})}^{-}\right]^{2}$ is the molar concentration of the alkaline solution, $\left(\mathrm{mol}^{-1}\right)$, and $\mathrm{p}_{\mathrm{H}_{2}}=\mathrm{p}_{2 \text {, out }}$, that is, the $\mathrm{H}_{2}$ partial pressure in atmosphere at the $\mathrm{CV} 2$ outlet.

The dimensionless net heat transfer in CV3 is given by

$$
\tilde{\mathrm{Q}}_{3}=-\tilde{\mathrm{Q}}_{23}+\tilde{\mathrm{Q}}_{\mathrm{w} 3}+\tilde{\mathrm{Q}}_{34}+\tilde{\mathrm{Q}}_{3 \mathrm{ohm}}
$$

The heat transfer rate between CV3 and CV4 (the alkaline membrane) is dominated by conduction; therefore,

$$
\begin{aligned}
\tilde{\mathrm{Q}}_{34}= & -\left(1-\phi_{3}\right)\left(\theta_{3}-\theta_{4}\right) \tilde{A}_{s} 2 \tilde{k}_{s, a} \tilde{k}_{m e m b} /\left(\xi_{4} \tilde{k}_{s, a}\right. \\
& \left.+\xi_{3} \tilde{k}_{m e m b}\right)
\end{aligned}
$$

where $\mathrm{k}_{\mathrm{memb}}=\mathrm{k}_{\mathrm{sol}} \phi_{4}+\mathrm{k}_{\mathrm{cel}}\left(1-\phi_{4}\right), \mathrm{k}_{\mathrm{sol}}$ is the thermal conductivity of the solution in the pore, and $k_{\mathrm{cel}}$ is the thermal conductivity or the porous solid material $[25,30]$, in this case cellulose.

The mass and energy balances for CV3, together with the anode reaction equation, deliver the relations

$$
\begin{aligned}
\dot{\mathrm{n}}_{\mathrm{H}_{2}} & =\frac{\dot{\mathrm{m}}_{\mathrm{f}}}{M_{\mathrm{H}_{2}}} \\
\dot{\mathrm{n}}_{\mathrm{H}_{2} \mathrm{O}} & =2 \dot{\mathrm{n}}_{\mathrm{H}_{2}} \\
\dot{\mathrm{m}}_{\mathrm{H}_{2} \mathrm{O}} & =2 \dot{\mathrm{n}}_{\mathrm{H}_{2}} \mathrm{M}_{\mathrm{H}_{2} \mathrm{O}} \\
\dot{\mathrm{n}}_{\mathrm{OH}^{-}} & =2 \dot{\mathrm{n}}_{\mathrm{H}_{2}} \\
\dot{\mathrm{m}}_{\mathrm{OH}^{-}} & =2 \dot{\mathrm{n}}_{\mathrm{H}_{2}} \mathrm{M}_{\mathrm{OH}^{-}}
\end{aligned}
$$

and

$$
\tilde{\mathrm{Q}}_{3}-\Delta \tilde{\mathrm{H}}_{3}+\Delta \tilde{\mathrm{G}}_{3}=0
$$

where $\left(\Delta \tilde{\mathrm{H}}_{3}, \Delta \tilde{\mathrm{G}}_{3}\right)=\dot{\mathrm{n}}_{\mathrm{H}_{2}}\left(\Delta \mathrm{H}_{3}, \Delta \mathrm{G}_{3}\right) / \dot{\mathrm{m}}_{\mathrm{ref}} \mathrm{c}_{\mathrm{p}, \mathrm{f}} \mathrm{T}_{\infty}$.

The chemical reaction at the cathode reaction layer (CV5) is

$$
\frac{1}{2} \mathrm{O}_{2(\mathrm{~g})}+2 \mathrm{H}_{2} \mathrm{O}_{(\mathrm{l})}+2 \mathrm{e}^{-} \rightarrow 2 \mathrm{OH}_{(\mathrm{aq})}^{-}
$$

Therefore, the energy balances for CV4 state that

$$
\begin{aligned}
& \tilde{\mathrm{Q}}_{\mathrm{w}_{4}}+\tilde{\mathrm{Q}}_{45}+\tilde{\mathrm{Q}}_{4 \mathrm{ohm}}-\tilde{\mathrm{Q}}_{34}+\tilde{\mathrm{H}}_{\mathrm{OH}^{-}}\left(\theta_{5}\right)-\tilde{\mathrm{H}}_{\mathrm{OH}^{-}}\left(\theta_{4}\right) \\
& +\tilde{\mathrm{H}}_{\mathrm{H}_{2} \mathrm{O}}\left(\theta_{3}\right)-\tilde{\mathrm{H}}_{\mathrm{H}_{2} \mathrm{O}}\left(\theta_{4}\right)=0
\end{aligned}
$$

where

$$
\tilde{\mathrm{Q}}_{45}=\frac{-\left(1-\phi_{5}\right)\left(\theta_{4}-\theta_{5}\right) 2 \tilde{\mathrm{A}}_{\mathrm{s}} \mathrm{k}_{\mathrm{s}, \mathrm{c}} \mathrm{k}_{\mathrm{memb}}}{\xi_{4} \tilde{\mathrm{k}}_{\mathrm{s}, \mathrm{c}}+\xi_{5} \tilde{\mathrm{k}}_{\mathrm{memb}}}
$$

Equations (19) and (25) and the conservation of mass in CV4 require that $2 \dot{\mathrm{n}}_{\mathrm{H}_{2}}=\dot{\mathrm{n}}_{\mathrm{OH}^{-} \text {,out }}=\dot{\mathrm{n}}_{\mathrm{OH}^{-}, \text {in }}=2 \dot{\mathrm{n}}_{\mathrm{O}_{2}}$, $2 \dot{\mathrm{n}}_{\mathrm{H}_{2}}=\dot{\mathrm{n}}_{\mathrm{H}_{2} \mathrm{O}, \text { in }}=\dot{\mathrm{n}}_{\mathrm{H}_{2} \mathrm{O}, \text { out }}=2 \dot{\mathrm{n}}_{\mathrm{O}_{2}}$.
The CV5 dimensionless temperature is obtained by

$$
\tilde{\mathrm{Q}}_{\mathrm{w} 5}+\tilde{\mathrm{Q}}_{56}+\tilde{\mathrm{Q}}_{5 \mathrm{ohm}}-\tilde{\mathrm{Q}}_{45}-\Delta \tilde{\mathrm{H}}_{5}+\Delta \tilde{\mathrm{G}}_{5}=0
$$

where

$$
\tilde{\mathrm{Q}}_{56}=\frac{-2 \tilde{\mathrm{k}}_{\mathrm{s}, \mathrm{c}}\left(1-\phi_{6}\right) \tilde{\mathrm{A}}_{\mathrm{s}}\left(\theta_{5}-\theta_{6}\right)}{\xi_{5}+\xi_{6}}
$$

and where $\left(\Delta \tilde{\mathrm{H}}_{5}, \Delta \tilde{\mathrm{G}}_{5}\right)=\dot{\mathrm{n}}_{\mathrm{O}_{2}}\left(\Delta \mathrm{H}_{5}, \Delta \mathrm{G}_{5}\right) / \dot{\mathrm{m}}_{\mathrm{ref}} \mathrm{c}_{\mathrm{p}, \mathrm{f}} \mathrm{T}_{\infty}$ is the mass balance delivers that $\dot{\mathrm{n}}_{\mathrm{H}_{2} \mathrm{O} \text {, in }}=2 \dot{\mathrm{n}}_{\mathrm{H}_{2} \mathrm{O} \text {, out }}=$ $\dot{\mathrm{n}}_{\mathrm{O}_{2}}, \dot{\mathrm{n}}_{\mathrm{OH}_{\mathrm{out}}^{-}}=2 \dot{\mathrm{n}}_{\mathrm{O}_{2}}$.

The enthalpy change during cathode reaction is $\Delta \mathrm{H}_{5}=$ $\sum_{\text {product }}\left[\mathrm{v}_{\mathrm{i}} \mathrm{H}_{\mathrm{i}}\left(\mathrm{T}_{\mathrm{i}}\right)\right]-\sum_{\text {reactan ts }}\left[\mathrm{v}_{\mathrm{i}} \mathrm{H}_{\mathrm{i}}\left(\mathrm{T}_{\mathrm{i}}\right)\right]$ while $\mathrm{W}_{\mathrm{e} 5}=-\Delta \mathrm{G}_{5}$. The CV5 reaction quotient is $\mathrm{Q}_{5}=\left[\mathrm{OH}_{\text {(aq) }}^{-}\right]^{2} / \mathrm{p}_{\mathrm{O}_{2}}^{1 / 2}$, where $\mathrm{p}_{\mathrm{O}_{2}}=\mathrm{p}_{6, \text { out }}$

The dimensionless temperature for CV6 is given by

$$
\begin{aligned}
& \tilde{\mathrm{Q}}_{\mathrm{w} 6}+\tilde{\mathrm{Q}}_{67}-\tilde{\mathrm{Q}}_{56}+\psi_{\mathrm{H}_{\mathrm{O}_{2}}} \frac{\mathrm{c}_{\mathrm{p}, \mathrm{ox}}}{\mathrm{c}_{\mathrm{p}, \mathrm{f}}}\left(\theta_{7}-\theta_{6}\right)+\tilde{\mathrm{H}}\left(\theta_{5}\right)_{\mathrm{H}_{2} \mathrm{O}} \\
& -\tilde{\mathrm{H}}\left(\theta_{6}\right)_{\mathrm{H}_{2} \mathrm{O}}=0
\end{aligned}
$$

where

$$
\tilde{\mathrm{Q}}_{67}=\tilde{\mathrm{h}}_{7} \tilde{\mathrm{A}}_{\mathrm{s}}\left(1-\phi_{6}\right)\left(\phi_{7}-\phi_{7}\right)
$$

and

$$
\tilde{\mathrm{h}}_{7}=\mathrm{h}_{7} \mathrm{~V}_{\mathrm{T}}^{2 / 3} / \dot{\mathrm{m}}_{\mathrm{ref}} \mathrm{c}_{\mathrm{p}, \mathrm{f}}
$$

The balances for energy in the oxidant channel (CV7) yield

$$
\begin{aligned}
& \tilde{\mathrm{Q}}_{7}+\psi_{\mathrm{ox}} \frac{\mathrm{c}_{\mathrm{p}, \mathrm{ox}}}{\mathrm{c}_{\mathrm{p}, \mathrm{f}}}\left(\theta_{\mathrm{ox}}-\theta_{7}\right)+\tilde{\mathrm{H}}\left(\theta_{6}\right)_{\mathrm{H}_{2} \mathrm{O}} \\
& -\tilde{\mathrm{H}}\left(\theta_{7}\right)_{\mathrm{H}_{2} \mathrm{O}}=0
\end{aligned}
$$

The dimensionless net heat transfer rate in CV7 is $\tilde{Q}_{7}=$ $-\tilde{\mathrm{Q}}_{67}+\tilde{\mathrm{Q}}_{\mathrm{w} 7}+\tilde{\mathrm{Q}}_{7 \mathrm{ohm}}$.

Based on the electrical conductivities and geometry of each compartment, the electrical and ionic resistances, $\beta(\Omega)$, are given by

$$
\begin{aligned}
& \beta_{i}=\frac{\xi_{i}}{\tilde{A}_{S} V_{T}^{1 / 3} \sigma_{i}\left(1-\phi_{i}\right)}, \quad i=1,2,6,7 \\
& \beta_{i}=\frac{\xi_{i}}{\tilde{A}_{S} V_{T}^{1 / 3} \sigma_{i} \phi_{i}}, \quad i=3,4 \text { and } 5
\end{aligned}
$$

where $\phi_{1}=\phi_{7}=0$ and $\phi_{4}=1$. The conductivities of the diffusive layer, $\sigma_{2}$ and $\sigma_{6}$, are the carbon-phase conductivities [31].

For $\sigma_{i}=\sigma_{\text {solution }}=-2.041 \mathrm{M}-0.0028 \mathrm{M}^{2}+0.005332 \mathrm{MT}_{\mathrm{i}}+$ 207.2 $\mathrm{MT}_{\mathrm{i}}^{-1}+0.001043 \mathrm{M}^{3}-3 \cdot 10^{-7} \mathrm{MT}^{2}, \mathrm{i}=3,4,5$ [32]. And the conductivities of CV1 and CV7, $r m \sigma_{1}$ and $\sigma_{7}$, are given by the electrical conductivity of the bipolar plate material.

The dimensionless potential and the dimensionless overpotential are defined in terms of a given reference voltage, $\mathrm{V}_{\text {ref }}=1 \mathrm{~V}$, so that $\tilde{\mathrm{V}}_{\mathrm{i}}=\mathrm{V}_{\mathrm{i}} / \mathrm{V}_{\text {ref }}$ and $\tilde{\eta}_{\mathrm{i}}=\eta_{\mathrm{i}} / \mathrm{V}_{\text {ref }}$.

The actual potential $\left(\tilde{V}_{i}\right)$ provided by a fuel cell results from the combination of anode irreversible potential $\left(\tilde{\mathrm{V}}_{\mathrm{i}, \mathrm{a}}\right)$, cathode 
irreversible potential $\left(\tilde{\mathrm{V}}_{\mathrm{i}, \mathrm{c}}\right)$, and the ohmic loss $\left(\tilde{\eta}_{\text {ohm }}\right)$ that occurs throughout the fuel cell between CV1 and CV7, as follows:

$$
\begin{aligned}
\tilde{\mathrm{V}}_{\mathrm{i}} & =\tilde{V}_{i, a}+\tilde{V}_{i, c}-\tilde{\eta}_{\text {ohm }} \\
\tilde{\eta}_{\mathrm{ohm}} & =\frac{I}{V_{\text {ref }}} \sum_{i=1}^{7} \beta_{i}
\end{aligned}
$$

The reversible electrical potentials at the anode and cathode are respectively given by the Nernst equation, as follows:

$$
\begin{aligned}
\mathrm{V}_{\mathrm{e}, \mathrm{j}} & =V_{e, j}^{\circ}-\frac{\bar{R} T_{i}}{n F} \ln Q_{i}(\mathrm{i}=3,5 \text { and } \mathrm{j} \\
& =\mathrm{a}, \mathrm{c}, \text { respectively })
\end{aligned}
$$

where $\mathrm{V}_{\mathrm{e}, \mathrm{j}}=\Delta \mathrm{G}_{\mathrm{i}} /(-n F), \mathrm{V}_{\mathrm{e}, \mathrm{j}}^{\circ}=\Delta \mathrm{G}_{\mathrm{i}}^{\circ} /(-\mathrm{nF})$.

At the reaction layers, there are two mechanisms for potential losses: (i) charge transfer, and (ii) mass diffusion. The potential losses at the anode $\left(\eta_{\mathrm{a}}\right)$ and cathode $\left(\eta_{\mathrm{c}}\right)$ due to charge transfer are obtained implicitly from the Butler-Volmer equation for a given current I [33, 34], as follows:

$$
\frac{\mathrm{I}}{\mathrm{A}_{\mathrm{i}, \text { wet }}}=i_{\mathrm{o}, \mathrm{j}}\left[e^{\frac{\left(1-\alpha_{j}\right) \eta_{j} F}{\bar{R} T_{i}}}-e^{\frac{\alpha_{j} \eta_{j} F}{\bar{R} T_{i}}}\right](\mathrm{i}=3,5 \text { and } \mathrm{j}
$$

$$
=\mathrm{a}, \mathrm{c}, \text { respectively) }
$$

where $\alpha_{j}$ are the anode and cathode charge transfer coefficients, and $i_{0, j}$ the anode and cathode exchange current densities, respectively.

The potential losses due to mass diffusion are [33]

$$
\begin{aligned}
\eta_{\mathrm{d}, \mathrm{j}} & =\frac{\bar{R} T_{i}}{n F} \ln \left(1-\frac{I}{A_{i, w e t} i_{\text {Lim }, j}}\right)(\mathrm{i}=3,5 \text { and } \mathrm{j} \\
& =\mathrm{a}, \mathrm{c}, \text { respectively })
\end{aligned}
$$

The limiting current densities in the anode and cathode $\left(i_{\text {Lim }, j}\right)$ represent borderline cases for mass transfer, when the concentration of reactants in the catalyst layer located at the interface with the gas diffusion layer drops to zero $\left(P_{2, \text { out }}=0\right.$ and $\left.P_{6, \text { out }}=0\right)$. The limit current density is the maximum current that a fuel cell can provide; for higher current values, the system collapses. Then, Eq. (17) is rewritten as follows:

$$
i_{\text {Lim, }, j}=\frac{P_{f} p_{\infty} D_{i} n F}{M_{H_{2}} L_{i} R_{f} T_{\infty} \theta_{i}} \text { (i }=2,6 \text { and } j=a, c \text {, respectively) }
$$

\begin{tabular}{|c|c|}
\hline $\mathrm{B}=0.156$ & $\mathrm{R}_{\mathrm{ox}}=0.2598 \mathrm{~kJ} \mathrm{~kg}^{-1} \mathrm{~K}^{-1}$ \\
\hline $\mathrm{c}_{\mathrm{p}, \mathrm{f}}=14.95 \mathrm{~kJ} \mathrm{~kg}^{-1} \mathrm{~K}^{-1}$ & $\mathrm{~V}_{\text {ref }}=1 \mathrm{~V}$ \\
\hline$c_{\mathrm{p}, \mathrm{ox}}=0.91875 \mathrm{~kJ} \mathrm{~kg}^{-1} \mathrm{~K}^{-1}$ & $\mathrm{~V}_{\mathrm{T}}=7.69 \times 10^{-5} \mathrm{~m}^{3}$ \\
\hline $\mathrm{c}_{\mathrm{v}, \mathrm{f}}=10.8 \mathrm{~kJ} \mathrm{~kg}^{-1} \mathrm{~K}^{-1}$ & $\left(\alpha_{a}, \alpha_{c}\right)=(0.75,45)$ \\
\hline$c_{\mathrm{v}, \mathrm{Ox}}=0.659375 \mathrm{~kJ} \mathrm{~kg}^{-1} \mathrm{~K}^{-1}$ & $\tilde{\mathrm{h}}$ \\
\hline $\mathrm{I}_{\mathrm{ref}}=1 \mathrm{~A}$ & $\mathrm{H}_{\mathrm{i}}\left(\mathrm{T}_{\mathrm{i}}\right)$ \\
\hline $\mathrm{k}_{\mathrm{f}}=0.182 \mathrm{~W} \mathrm{~m}^{-1} \mathrm{~K}^{-1}$ & $\mathrm{M}=6.9 \mathrm{~mol} / \mathrm{L}$ \\
\hline $\mathrm{k}_{\mathrm{ox}}=0.0266 \mathrm{~W} \mathrm{~m}^{-1} \mathrm{~K}^{-1}$ & $\zeta_{1}, \zeta_{7}=2$ \\
\hline $\mathrm{k}_{\mathrm{p}}=0.12 \mathrm{~W} \mathrm{~m}^{-1} \mathrm{~K}^{-1}$ & $\mathrm{U}_{\mathrm{wi}}=50 \mathrm{~W} \mathrm{~m}^{-2} \mathrm{~K}^{-1}, \mathrm{i}=1$ to 7 \\
\hline$\dot{\mathrm{m}}_{\mathrm{ref}}=5.10^{-4} \mathrm{~kg} \mathrm{~s}^{-1}$ & $q=2.1$ \\
\hline $\mathrm{p}_{\mathrm{f}}=\mathrm{p}_{\mathrm{ox}}=0.01 \mathrm{MPa}=1.5 \mathrm{psi}$ & $\mathrm{R}_{\mathrm{f}}=4.157 \mathrm{~kJ} \mathrm{~kg}^{-1} \mathrm{~K}^{-1}$ \\
\hline $\mathrm{p}_{\infty}=0.1 \mathrm{MPa}=1 \mathrm{~atm}$ & $\mathrm{~T}_{\mathrm{f}}, \mathrm{T}_{\mathrm{ox}}, \mathrm{T}_{\infty}=290.15 \mathrm{~K}$ \\
\hline $\mathrm{K}_{2}, \mathrm{~K}_{6}=4 \times 10^{-18} \mathrm{~m}^{2}$ & $\left(\mathrm{i}_{0, \mathrm{a}}, \mathrm{i}_{0, \mathrm{c}}\right)=\left(1 ., 10^{-7}\right) \mathrm{A} \mathrm{m}^{-2}$ \\
\hline $\mathrm{K}_{3}, \mathrm{~K}_{5}=4 \times 10^{-10} \mathrm{~m}^{2}$ & \\
\hline
\end{tabular}

The resulting electrical potentials at the anode and cathode are respectively given by

$$
\tilde{\mathrm{V}}_{\mathrm{i}, \mathrm{j}}=\tilde{\mathrm{V}}_{\mathrm{e}, \mathrm{j}}-\tilde{\eta}_{\mathrm{j}}-\left|\tilde{\eta}_{\mathrm{d}, \mathrm{j}}\right|(\mathrm{j}=\mathrm{a}, \mathrm{c})
$$

The absolute values of $\tilde{\eta}_{\mathrm{d}, \mathrm{j}}$ are used, because there could be $\tilde{\eta}_{\mathrm{d}, \mathrm{j}}<0$ (cathode overpotential).
Table 1 Physical properties used in the parametric analysis of a single AMFC prototype

The available power provided by a fuel cell $\left(\tilde{\mathrm{W}}_{\text {net }}\right)$ is obtained subtracting the energy needed to supply the fuel cell with fuel and oxidant $\left(\tilde{\mathrm{W}}_{\mathrm{p}}\right)$. Therefore, the total net power (available for utilization) of the fuel cell is

$$
\tilde{\mathrm{W}}_{\text {net }}=\tilde{\mathrm{W}}-\tilde{\mathrm{W}}_{\mathrm{p}}
$$

where $\tilde{\mathrm{W}}=\tilde{\mathrm{V}}_{\mathrm{i}} \tilde{\mathrm{I}}$ is the total fuel cell electrical power output, $\tilde{\mathrm{I}}=\mathrm{I} / \mathrm{I}_{\mathrm{ref}}$, and $\mathrm{I}_{\mathrm{ref}}=1 \mathrm{~A}$. The dimensionless pumping power, $\tilde{\mathrm{W}}_{\mathrm{p}}$, is given by

$$
\tilde{\mathrm{W}}_{\mathrm{p}}=\psi_{\mathrm{f}} \mathrm{S}_{\mathrm{f}} \frac{\theta_{\mathrm{i}}}{\mathrm{P}_{\mathrm{i}}} \Delta \mathrm{P}_{1}+\psi_{\mathrm{ox}} \mathrm{S}_{\mathrm{ox}} \frac{\theta_{7}}{\mathrm{P}_{7}} \Delta \mathrm{P}_{7}
$$

where $S_{i}=\frac{m_{\text {ref }} T_{\infty} R_{i}}{V_{\text {ref }} I_{\text {ref }}}, i=f$, ox.

\section{Results and Discussion}

The numerical simulation of the single AMFC is performed by solving Eqs. (7), (15), (17), (24), (26), (28), (30), and (33),

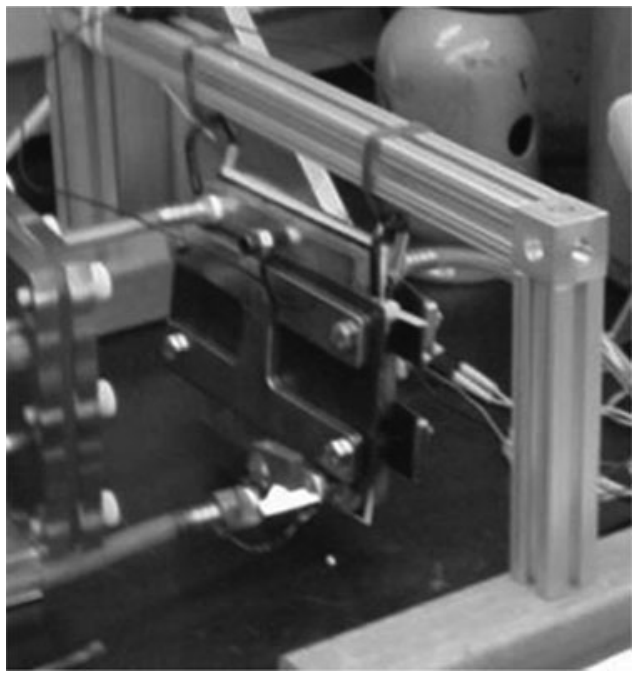

Figure 3 AMFC prototype. 


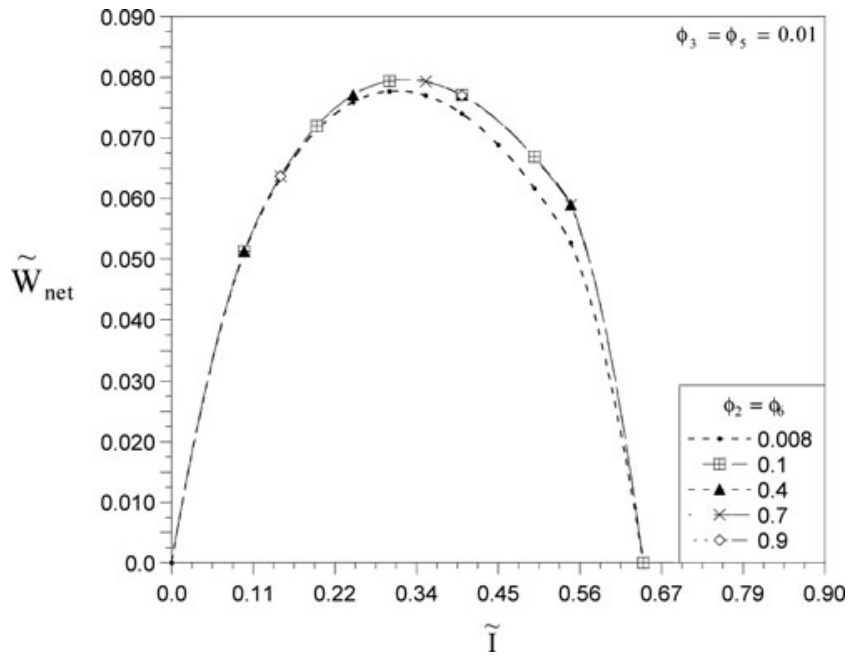

Figure 4 Power curves as function of diffusive layer porosity.

which form a system of nine algebraic equations (Eq. (17) represents the pressure of hydrogen and oxygen, meaning it actually corresponds to two equations). The unknowns are $\theta_{\mathrm{i}}$ and $\mathrm{P}_{\mathrm{i}}$, that is, the temperatures in the seven control volumes, and the gas pressures in CV2 and CV6. Once the temperatures and pressures are known, the electrical potentials and power are calculated for any assumed current level.

Pressures are related to temperatures via Eq. (17). The system reduces to seven nonlinear algebraic equations, in which the unknowns are the temperatures of the seven control volumes.

This system was solved with a FORTRAN code, using a quasi-Newton method [35], where a tolerance for the norm of the residual vector less or equal to $10^{-6}$ was considered to obtain a converged solution. The data available in the literature [20] and assumed physical properties needed for the present calculation are presented in Table 1. The alkaline solution used in this study is a $\mathrm{KOH}$ solution with concentration of $30 \mathrm{wt} \%$ or $6.9 \mathrm{~mol} / \mathrm{L}$. Figure 3 shows the prototype for

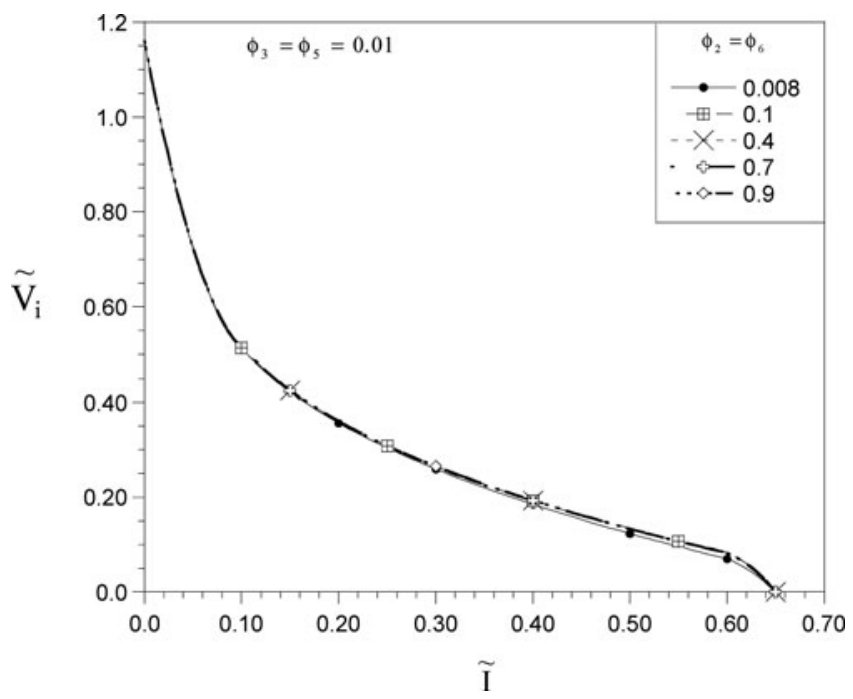

Figure 5 Polarization curves as function of diffusion layer porosity.

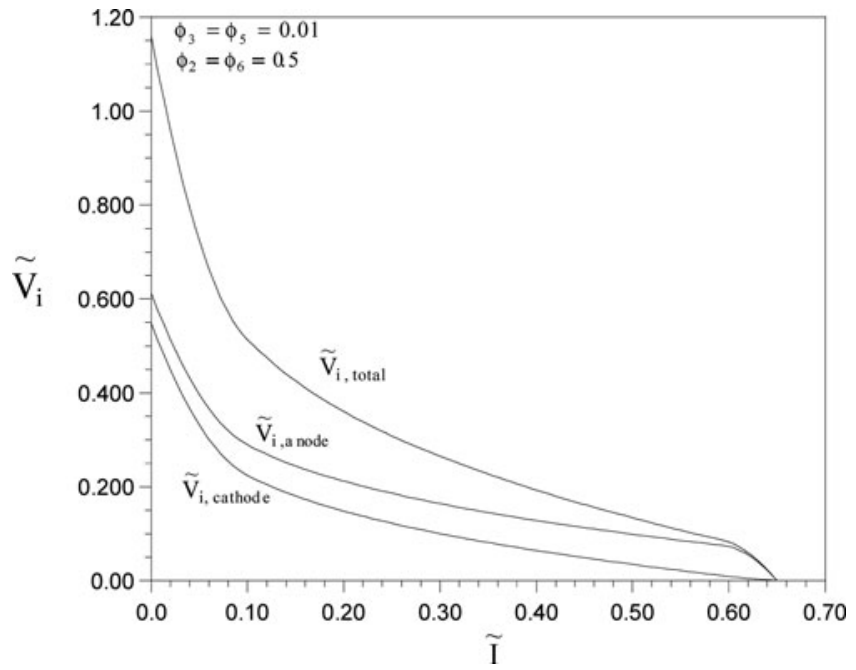

Figure 6 Polarization curves of both sides of the AMFC for $\phi_{2}=\phi_{6}=0.5$ and $\phi_{3}=\phi_{5}=0.01$.

which the internal structure was measured directly in laboratory. The dimensionless parameters were then calculated, obtaining $\xi_{1} / \xi_{\mathrm{x}}=\xi_{7} / \xi_{\mathrm{x}}=0.374, \xi_{2} / \xi_{\mathrm{x}}=\xi_{6} / \xi_{\mathrm{x}}=0.051$, $\xi_{3} / \xi_{\mathrm{x}}=\xi_{5} / \xi_{\mathrm{x}}=0.027, \xi_{4} / \xi_{\mathrm{x}}=0.094, \xi_{\mathrm{x}}=0.125$, $\xi_{\mathrm{y}}=\xi_{\mathrm{z}}=2.822$ and $\xi_{\mathrm{t}} / \xi_{\mathrm{y}}=0.047, \xi_{\mathrm{c}} / \xi_{\mathrm{y}}=0.023$, with $\xi_{\mathrm{t}}=0.00258 \mathrm{~m}^{3}$.

The porosities of the diffusive layer $\left(\phi_{2}, \phi_{6}\right)$ and reaction layer $\left(\phi_{3}, \phi_{5}\right)$ are the parameters varied during the simulation to investigate their influence in the power output of the fuel cell when the thickness of the electrode is kept constant, meaning the total volume of the fuel cell is a constraint for a future optimization analysis.

The same Pt/C-based electrode was considered for the anode and cathode sides of the AMFC. For this investigation, $\phi_{2}=\phi_{6}$ and $\phi_{3}=\phi_{5}$. Figure 4 shows the power curves obtained for $\phi_{3}=\phi_{5}=0.01$ and $0.008 \leq \phi_{2}=\phi_{6} \leq 0.9$. The lower power output is obtained for the lowest diffusive layer porosity, due to

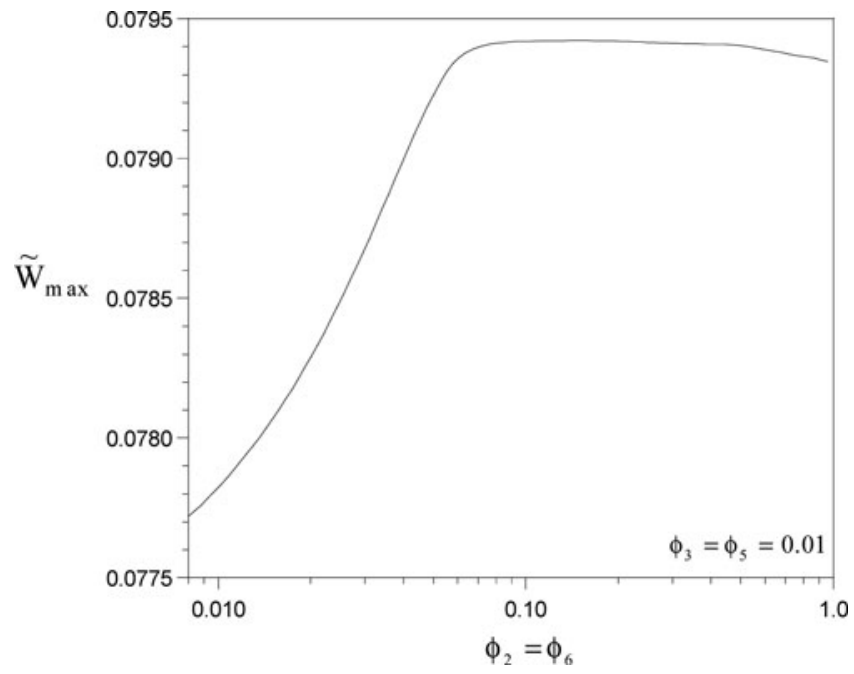

Figure 7 Maximum net power output as function of the porosity of the diffusive layer. 


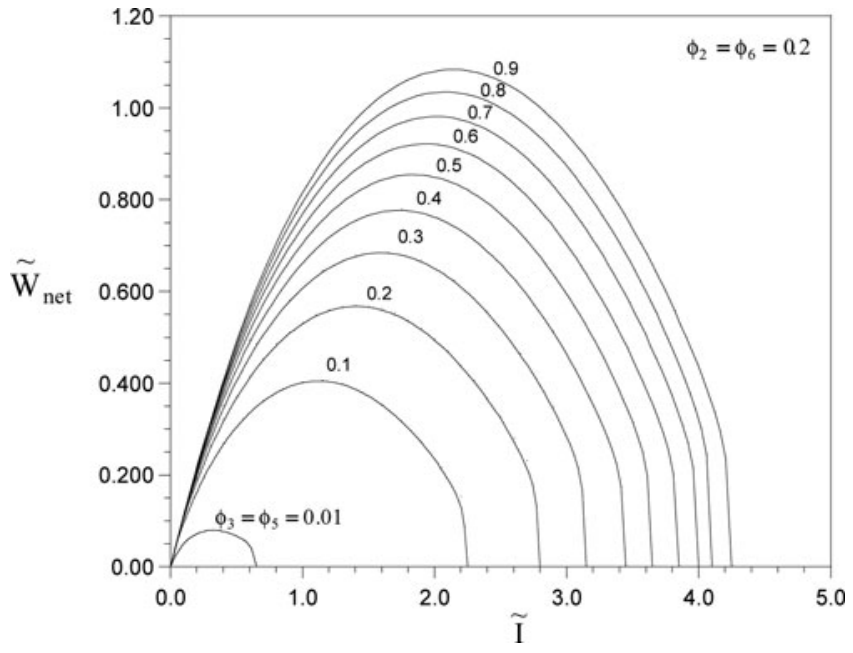

Figure 8 Power curves as function of reaction layer porosity.

very low diffusion of reactant gases that reach the reactive layer. The power curves for the $0.1 \leq \phi_{2}=\phi_{6} \leq 0.9$ collapse, indicating no improvement of power output as the porosity of the diffusive layer increases. Since the power output is the result of the electrochemical reactions at the reaction layers, the porosity of the diffusion layers has no influence on the rate of reactions, which is determined by the physical properties of CV3 and CV5, which were kept constant, $\phi_{3}=\phi_{5}=0.01$. The polarization curves presented in Figure 5 show the same trend. The polarization curve obtained for the lowest diffusive layer porosity is slightly lower than that of the other ones, demonstrating no improvement of fuel cell performance as the diffusion layer porosity increases. It can be seen that the maximum current is the same for all ranges of diffusive layer porosity studied. This indicates that the maximum current is a function of properties of the reaction layer. Increasing the porosity of the diffusive layer, the flow of reactants to the reaction sites is facilitated; however, when the reaction sites are not capable of consuming the reactants, no improvement in the output will be achieved.

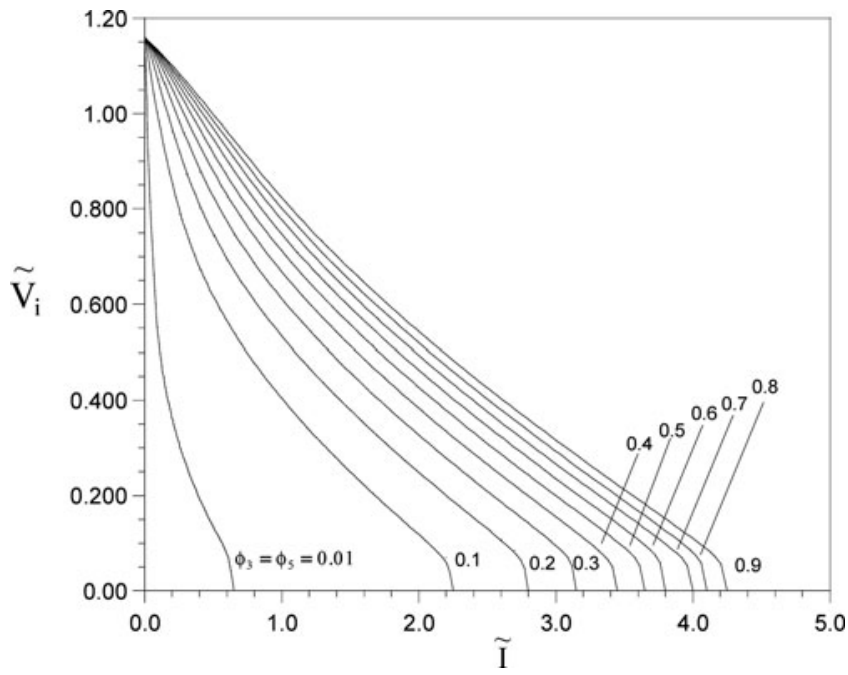

Figure 9 Polarization curves as function of reaction layer porosity.

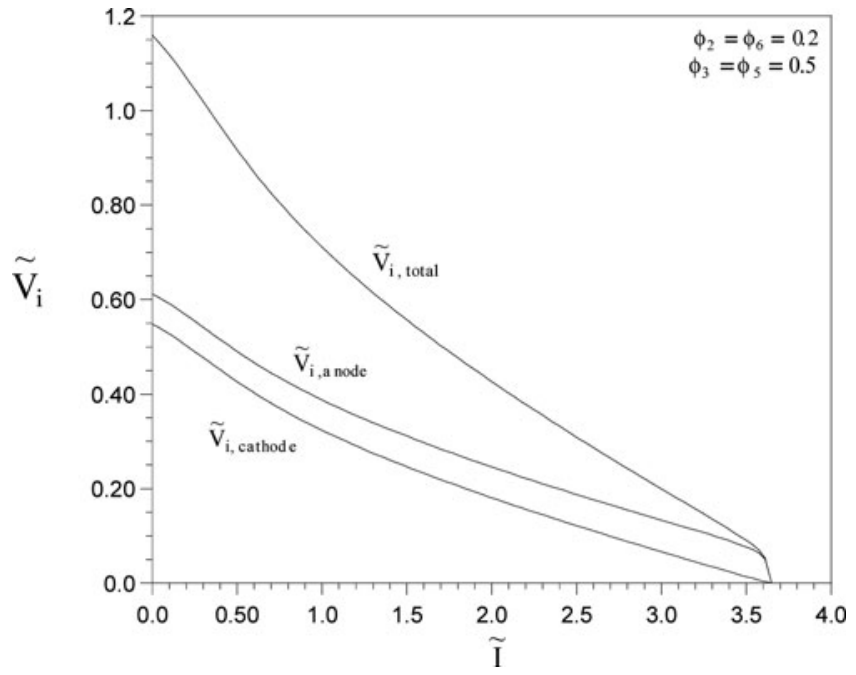

Figure 10 Polarization curves of both sides of the AMFC for $\phi_{2}=\phi_{6}=0.2$ and $\phi_{3}=\phi_{5}=0.5$.

The polarization curves for each side of the AMFC are shown in Figure 6. It can be seen that the cathode side is the one that presents more losses, limiting the total fuel cell output. Figure 7 shows the maximum power output as a function of the diffusive layer porosity. No significant improvement of power output is observed for diffusive layer porosity greater then 0.05 .

Power curves for $\phi_{2}=\phi_{6}=0.2$ and $0.01 \leq \phi_{3}=\phi_{5} \leq$ 0.9 are shown in Figure 8. As can be expected, the higher the porosity of the catalytic layers, the more effective an electrode will be, since more solution will be absorbed and also a bigger superficial area will be available for the electrochemical reaction to occur. As can be seen in Figure 9, the maximum current increases as the porosity of the reaction layers increases, which can be explained by the presence of more reaction sites due to the increase of available superficial area.

As noticed in the previous case, the cathode performance limits the total fuel cell output; Figure 10 shows the

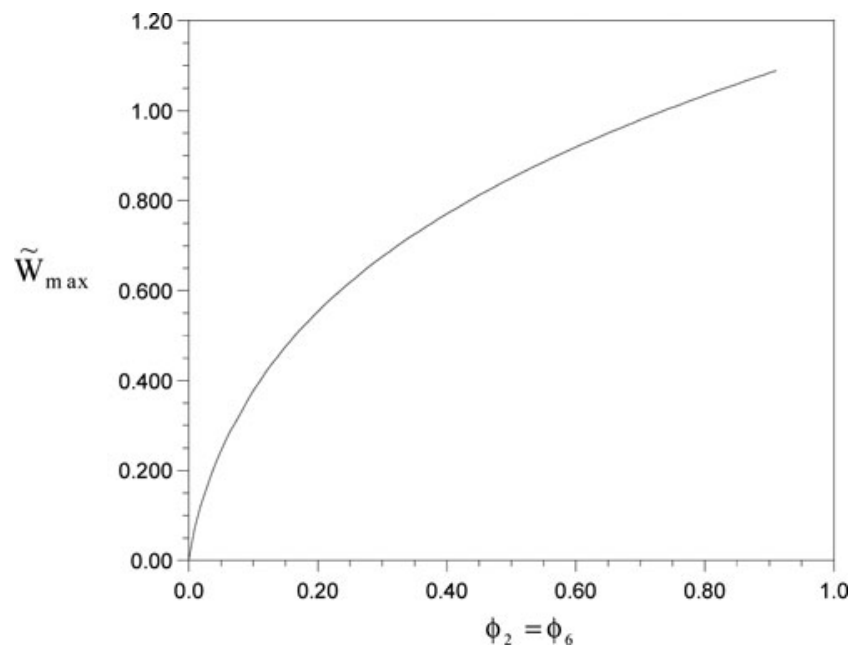

Figure 11 Maximum net power output as function of the porosity of the reaction layer. 
polarization curves for both sides of the fuel cell, $\phi_{2}=\phi_{6}=0.2$ and $\phi_{3}=\phi_{5}=0.5$. Since the porosity of the reaction layer is higher than that of the case presented in Figure 6, the maximum current achieved is also higher. However, the cathode side of the fuel cell also presents more losses than the anode side, which causes the voltage at the cathode to drop to zero faster.

According to Figure 11, the porosity of the reaction layers plays a key role in the achievement of the higher maximum net power. No optimum porosity for the reaction layer was found since the power output only increased as the reaction layer porosity increased. Manufacturing factors will determine how feasible it will be to fabricate an electrode with high porosity with the same thickness.

\section{Conclusions}

In this study, a mathematical model experimentally validated [20] was used as tool for the shown parametric analysis of a single AMFC. It was shown that when volume is a constraint in an optimization analysis, other physical properties can be targeted, for example, porosity of the diffusive and reaction layers. The study indicates that the increase of the porosity of the diffusive layer has no significant effect on the fuel cell output since the power is generated in the reaction layer. The increase of the porosity of the reaction layer was demonstrated to be an alternative to improve the output power of the AMFC prototype. For the dimensions and properties of the prototype considered, the cathode reaction layer is the part of the fuel cell that limits the increase of the fuel cell output since the voltage output at the cathode drops to zero faster than at the anode due to the irreversible overpotential losses.

\section{Nomenclature}

\section{A area, $\mathrm{m}^{2}$}

$\mathrm{A}_{\mathrm{c}} \quad$ total gas channel cross-section area, $\mathrm{m}^{2}$

$\mathrm{A}_{\mathrm{S}} \quad$ unit fuel cell cross-section area, $\mathrm{m}^{2}$

$\tilde{\mathrm{A}}$ dimensionless area

AMFC alkaline membrane fuel cell

B dimensionless constant

c specific heat, $\mathrm{kJ} \mathrm{kg}^{-1} \mathrm{~K}^{-1}$

$\mathrm{c}_{\mathrm{p}} \quad$ specific heat at constant pressure, $\mathrm{kJ} \mathrm{kg}^{-1} \mathrm{~K}^{-1}$

C constant, Eq. (11)

CV control volume

D Knudsen diffusion coefficient, $\mathrm{m}^{2} \mathrm{~s}^{-1}$

$\mathrm{D}_{\mathrm{h}} \quad$ gas channel hydraulic diameter, $\mathrm{m}$

f friction factor

F Faraday constant, $96,500 \mathrm{C} \mathrm{eq}^{-1}$

$\Delta G \quad$ molar Gibbs free energy change, $\mathrm{kJ} \mathrm{kmol}^{-1}$

$\Delta \tilde{G}$ dimensionless molar Gibbs free energy change $\mathrm{h}$

$\tilde{\mathrm{h}}$

$\Delta \mathrm{H}$

$\Delta \tilde{H}$

$\mathrm{H}_{\mathrm{i}}(\mathrm{T})_{\mathrm{i}}$

$\tilde{\mathrm{H}}_{\mathrm{i}}\left(\theta_{\mathrm{i}}\right)$

$\mathrm{i}_{\mathrm{o}, \mathrm{a}}, \mathrm{i}_{\mathrm{O}, \mathrm{c}}$

$\mathrm{i}_{\text {Lim, }, \mathrm{a}} \mathrm{i}_{\text {Lim,c }}$

I

$\tilde{\mathrm{I}}$

$\mathrm{j}$

$\mathrm{k}$

$\mathrm{K}$

$\mathrm{KOH}$

$\tilde{\mathrm{k}}$

$(I=3.1 \mathrm{~A})$

$\mathrm{L}_{\mathrm{c}}, \mathrm{L}_{\mathrm{t}}$

$\mathrm{L}_{\mathrm{x}}, \mathrm{L}_{\mathrm{y}}, \mathrm{L}_{\mathrm{z}}$

$\mathrm{m}$

$\dot{\mathrm{m}}$

M

n

$\dot{\mathrm{n}}$

$n_{c}$

$\mathrm{N}$

$\mathrm{p}$

$\tilde{\mathrm{p}}_{\mathrm{s}}$

$P$

$\mathrm{Pr}$

q

Q

Q

Q

$\mathrm{r}$

$\mathrm{R}$

$\overline{\mathrm{R}}$

$\mathrm{Re}_{\mathrm{Dh}}$

$\mathrm{S}$

$\Delta S$

$\mathrm{T}$

$\Delta \mathrm{T}$

u

$\tilde{\mathrm{u}}$

$\mathrm{U}$

V

V

$\mathrm{V}_{\mathrm{T}}$

$\mathrm{W}$

$\tilde{\mathrm{W}}$

$\tilde{\mathrm{W}}_{\text {net }}$ heat transfer coefficient, $\mathrm{W} \mathrm{m}{ }^{-2} \mathrm{~K}^{-1}$

dimensionless heat transfer coefficient

molar enthalpy change, $\mathrm{kJ} \mathrm{kmol}^{-1} \mathrm{H}_{2}$

dimensionless molar enthalpy change

molar enthalpy of formation at temperature $T_{i}$ of reactants and products, $\mathrm{kJ} \mathrm{kmol}^{-1}$ of compound $\mathrm{i}$

dimensionless molar enthalpy of formation at dimensionless temperature $\theta_{i}$ of reactants and products

exchange current densities, $\mathrm{A} \mathrm{m}^{-2}$

limiting current densities, $\mathrm{A} \mathrm{m}^{-2}$

current, A

dimensionles current

mass flux, $\mathrm{kg} \mathrm{m}^{2} \mathrm{~s}^{-1}$

thermal conductivity, $\mathrm{W} \mathrm{m}{ }^{-1} \mathrm{~K}^{-1}$

permeability

potassium hydroxide

dimensionless thermal conductivity

control volume length, $\mathrm{m}$

gas channels internal dimensions as shown in

Figure 1, m

fuel cell length, width and height, respectively, $\mathrm{m}$

mass, $\mathrm{kg}$

mass flow rate, $\mathrm{kg} \mathrm{s}^{-1}$

molar weight, $\mathrm{kg} \mathrm{kmol}^{-1}$

equivalent electron per mole of reactant, eq $\mathrm{mol}^{-1}$

molar flow rate, $\mathrm{kmol} \mathrm{s}^{-1}$

number of parallel ducts in gas channel

dimensionless global wall heat transfer coefficient

pressure, $\mathrm{N} \mathrm{m}^{-2}$

perimeter of cross-section, $\mathrm{m}$

dimensionless pressure

Prandtl number, $\mu c_{p} / k$

tortuosity

reaction quotient

heat transfer rate, $\mathrm{W}$

dimensionless heat transfer rate

pore radius, $\mathrm{m}$

ideal gas constant, $\mathrm{kJ} \mathrm{kg}^{-1} \mathrm{~K}^{-1}$

universal gas constant, $8.314 \mathrm{~kJ} \mathrm{kmol}^{-1} \mathrm{~K}^{-1}$

Reynolds number based on $\tau_{L, \text { set }}=0.96$

dimensionless conversion factor, Eq. (442.41)

molar entropy change, $\mathrm{kJ} \mathrm{kmol}^{-1}$

temperature, $\mathrm{K}$

temperature change, $\mathrm{K}$

mean velocity, $\mathrm{m} \mathrm{s}^{-1}$

dimensionless mean velocity

global wall heat transfer coefficient, $\mathrm{W} \mathrm{m}^{-2} \mathrm{~K}^{-1}$

electrical potential, $\mathrm{V}$

volume, $\mathrm{m}^{3}$

total volume, $\mathrm{m}^{3}$

electrical work, J

dimensionless fuel cell total electrical power

dimensionless fuel cell net power 


\begin{tabular}{|c|c|}
\hline$\tilde{\mathrm{W}}_{\mathrm{p}}$ & dimensionless required pumping power \\
\hline $\mathrm{X}$ & axial direction, Figure 1 \\
\hline$[\cdot]$ & molar concentration of a substance, $\mathrm{mol} \mathrm{L}^{-1}$ \\
\hline Greek $S y$ & mbols \\
\hline$\alpha_{a}, \alpha_{c}$ & anode and cathode charge transfer coefficients \\
\hline$\beta$ & electrical resistance, $\Omega$ \\
\hline$\delta$ & gas channel aspect ratio \\
\hline$\varepsilon$ & standard deviation \\
\hline$\xi$ & stoichiometric ratio \\
\hline$\eta$ & potential loss, $\mathrm{V}$ \\
\hline$\eta_{\mathrm{a}}, \eta_{\mathrm{c}}$ & anode and cathode charge transfer overpotentials, $\mathrm{V}$ \\
\hline$\eta_{\mathrm{d}, \mathrm{a}}, \eta_{\mathrm{d}, \mathrm{c}}$ & anode and cathode mass diffusion overpotentials, $\mathrm{V}$ \\
\hline$\tilde{\eta}_{\mathrm{a}}, \tilde{\eta}_{\mathrm{c}}$ & $\begin{array}{l}\text { dimensionless anode and cathode charge transfer } \\
\text { overpotentials }\end{array}$ \\
\hline$\tilde{\eta}_{\mathrm{d}, \mathrm{a}}, \tilde{\eta}_{\mathrm{d}, \mathrm{c}}$ & $\begin{array}{l}\text { dimensionless anode and cathode mass diffusion } \\
\text { overpotentials }\end{array}$ \\
\hline$\tilde{\eta}_{\text {ohm }}$ & dimensionless fuel cell total ohmic potential loss \\
\hline$\theta$ & dimensionless temperature \\
\hline$\mu$ & viscosity, $\mathrm{kg} \mathrm{m}^{-1} \mathrm{~s}^{-1}$ \\
\hline$v_{\mathrm{i}}$ & reaction coefficient \\
\hline$\xi$ & dimensionless length \\
\hline$\rho$ & density, $\mathrm{kg} \mathrm{m}^{-3}$ \\
\hline$\sigma$ & electrical conductivity, $\Omega^{-1} \mathrm{~m}^{-1}$ \\
\hline$\phi$ & porosity \\
\hline 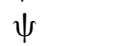 & dimensionless mass flow rate \\
\hline
\end{tabular}

\section{Subscripts}

$\begin{array}{ll}\text { a } & \text { anode } \\ (\mathrm{aq}) & \text { aqueous solution } \\ \mathrm{c} & \text { cathode or channel } \\ \mathrm{e} & \text { reversible } \\ \mathrm{f} & \text { fuel } \\ (\mathrm{g}) & \text { gaseous phase } \\ \mathrm{H}^{+} & \text {hydrogen cation } \\ \mathrm{H}_{2} & \text { hydrogen } \\ \mathrm{H}_{2} \mathrm{O} & \text { water } \\ \mathrm{i} & \text { irreversible } \\ \mathrm{i}, \mathrm{a} & \text { irreversible at the anode } \\ \mathrm{i}, \mathrm{c} & \text { irreversible at the cathode } \\ \mathrm{in} & \text { control volume inlet } \\ \mathrm{j} & \text { particular dimension of fuel cell geometry } \\ (\mathrm{l}) & \text { liquid phase } \\ \text { ohm } & \text { ohmic } \\ \text { out } & \text { control volume outlet } \\ \text { ox } & \text { oxidant } \\ \mathrm{O} \\ 2 & \text { oxygen } \\ \mathrm{p} & \text { polymer electroyte membrane } \\ \text { ref } & \text { reference level } \\ \mathrm{s}, \mathrm{a} & \text { anode solid side } \\ \mathrm{s}, \mathrm{c} & \text { cathode solid side } \\ \text { sol } & \text { solution }\end{array}$

$t$ thickness of the wall of gas channels

w wall

wet wetted

0 initial condition

$1, \ldots, 7$ control volume, Fig. 2.1

12 interaction between CV1 and CV2

23 interaction between $\mathrm{CV} 2$ and $\mathrm{CV} 3$

34 interaction between CV3 and CV4

45 interaction between CV4 and CV5

56 interaction between CV5 and CV6

67 interaction between CV6 and CV7

$\infty \quad$ ambient

\section{Superscript}

- standard conditions [gases at $1 \mathrm{~atm}, 25^{\circ} \mathrm{C}$, species in solution at $1 M$, where $M$ is the molarity $=($ moles solute $) /($ liters solution)]

$\sim$ dimensionless variable

\section{References}

[1] Cantoni, U., Alternative Fuels Utilization in Fuel Cells for Transportation, Society of Automotive Engineers-SAE, Paper 931816, 1993, doi 10.4271/931816.

[2] Linden, D., Handbook of Batteries and Fuel Cells, McGraw-Hill, New York, NY, 1984.

[3] Verma, A., Jha, A. K., and Basu, S., Manganese Dioxide as a Cathode Catalyst for a Direct Alcohol or Sodium Borohydride Fuel Cell With a Flowing Alkaline Electrolyte, Journal of Power Sources, vol. 141, pp. 30-34, 2005.

[4] Chatenet, M., Micoud, F., Roche, I., and Chainet, E., Kinetic of Sodium Borohydride Direct Oxidation and Oxygen Reduction in Sodium Hydroxide Electrolyte: Part I. Electro-Oxidation on $\mathrm{Au}$ and Ag Catalysts, Electrochimica Acta, vol. 51, pp. 5459-5467, 2006.

[5] Vieskstuch, W., Lamm, A., and Gasteuger, H. A., Handbook of Fuel Cells, vol. 2, John Wiley and Sons, New York, NY, 2003.

[6] Berger, C., Handbook of Fuel Cells Technology, Prentice Hall, Englewood Cliffs, NJ, 1968.

[7] Soica, D., Ogier, L., Akrour, L., Alloin, F., and Fauvarque, J.-F., Anionic Membrane Based on Polyepichlorhydrin Matrix for Alkaline Fuel Cell: Synthesis, Physical and Electrochemical Properties, Electrochimica Acta, vol. 53, pp. 1596-1603, 2007.

[8] Sollogoub, C., Guinault, A., Bonnebat, C., Bennjima, M., Akrout, L., Fauvarque, J. F., and Ogier, L., Formation and Characterization of Crosslinked Membranes for Alkaline Fuel Cells, Journal of Membrane Science, vol. 335, pp. 37-42, 2009.

[9] Bidault, F., Breet, D. J. L., Middleton, P.H., Anbson, N., and Brandon, N. P., A new Application for Nickel Foam 
in Alkaline Fuel Cells, International Journal of Hydrogen Energy, vol. 34, pp. 6977-6808, 2009.

[10] Wan, Y., Creber, K. A., Peppley, B., Bui, V. T., and Halliop, E., New Solid Polymer Electrolyte Membranes for Alkaline Fuel Cells, Polymer International, vol. 54, pp. 5-10, 2005.

[11] Sangeetha, D., Conductivity and Solvent Uptake of Proton Exchange Membrane Based on Polystyrene (EthyleneButylene) Polystyrene Triblock Polymer, European Polymer Journal, vol. 41, no. 11, pp. 2644-2652, 2005.

[12] Morikawa, J., Kobayahi, A., and Hashimoto, T., Thermal Diffusivity in a Binary Mixture of Poly (Phenylene Oxide) and Polystyrene, Thermochimica Acta, vol. 267, no. 1, pp. 289-296, 2005.

[13] Gülzow, E., Schulze, M., Steinhilber, G., and Bolwin, K., Carbon Dioxide Tolerance of Gas Diffusion Electrodes For Alkaline Fuel Cells, Proceedings of the Fuel Cell Seminar San Diego, p. 319, 1994.

[14] Valade, D., Boschet, F., Roualdes, S., and Ameduri, B., Preparation of Solid Alkaline Fuel Cell Binders Based on Fluorinated Poly(Diallydldimethylammonium Chloride)s [poly(DADMAC)] or Poly(chlorotrifluoroethyleneco-DADMAC) Copolymers, Journal of Polymer Science, vol. 47, pp. 2043-2058, 2009.

[15] Varcoe, J., Slade, R. C. T., Wright, G. L., and Chen, Y., Steady-State DC and Impedance Investigations of $\mathrm{H}_{2} / \mathrm{O}_{2}$ Alkaline Membrane Fuel Cells With Commercial Pt/C, $\mathrm{Ag} / \mathrm{C}$, and $\mathrm{Au} / \mathrm{C}$ Cathodes, Journal of Physical Chemistry $B$, vol. 110, pp. 21041-21049, 2006.

[16] Xu, T., Ion Exchange Membranes: State of Their Development and Perspective, Journal of Membrane Science, vol. 263, pp. 1-29, 2005.

[17] Varcoe, J. R., and Slade, R. C., Prospects for Alkaline Anion-Exchange Membranes in Low Temperature Fuel Cells, Fuel Cells, vol. 5, pp. 187-200, 2005.

[18] Smitha, B., Sridhar, S., and Khan, A. A., Solid Polymer Electrolyte Membranes for Fuel Cell, Journal of Membrane Science, vol. 259, pp. 10-26, 2005.

[19] Zhang, H., Lin, G., and Chen, J., The Performance Analysis and Multi-Objective Optimization of a Typical Alkaline Fuel Cell, Energy, vol. 36, pp. 4327-4332, 2011.

[20] Sommer, E. M., Martins, L. S., Vargas, J. V. C., Gardolinski, J. E. F. C., and Ordonez, J. C., Alkaline Membrane Fuel Cell (AMFC) Modeling and Experimental Validation, Journal of Power Sources, vol. 213, pp. 16-30, 2012.

[21] Jo, J., and Yi, S., A Computational Simulation of an Alkaline Fuel Cell, Journal of Power Sources, vol. 84, pp. 87-106, 1999.

[22] Vargas, J. V. C., and Bejan, A., Thermodynamic Optimization of Internal Structure in a Fuel Cell, International Journal of Energy Research, vol. 28, pp. 319-339, 2004.

[23] Baumann, A., Hauff, S., and Bolwin, K., Computer Simulation of Thermal Modeling of Alkaline Hydrogen/Oxygen
Fuel Cells, Journal of Power Sources, vol. 36, pp. 185-199, 1991.

[24] Shah, R. K., and London, A. L., Laminar Flow Forced Convection in Ducts, Supplement 1 to Advances in Heat Transfer, Academic Press, New York, NY, 1978.

[25] Bejan, A., Convection Heat Transfer, 2nd ed., Wiley, New York, NY, 1995.

[26] Bird, R. B., Stewart, W. E., and Lightfoot, E. N., Transport Phenomena, 2nd ed., Wiley, New York, NY, 2002.

[27] Newman, J. S., Electrochemical Systems, 2nd ed., Prentice Hall, Englewood Cliffs, NJ, pp. 255, 299, 461, 1991.

[28] Wesselingh, J. A., Vonk, P., and Kraaijeveld, G., Exploring the Maxwell-Stefan description of ion-exchange, The Chemical Engineering Journal and The Biochemical Engineering Journal, vol. 57, pp. 75-89, 1995.

[29] Masterton, W. L., and Hurley, C. N., Chemistry Principles \& Reactions, 3rd ed., Saunders College Publishing, Orlando, FL, 1997.

[30] Nield, D. A., and Bejan, A., Convection in Porous Media, 3rd ed., Springer, New York, NY. 2066.

[31] Kulikovsky, A. A., Divisek, J., and Kornyshev, A. A., TwoDimensional Simulation of Direct Methanol Fuel Cells-A New (Embedded) Type of Current Collector, Journal of the Electrochemical Society, vol. 147, pp. 953-959, 2000.

[32] Gilliam, R. J., Graydon, J. W., Kirk, D. W., and Thorpe, S. J., A Review of Specific Conductivities of Potassium Hydroxide Solutions for Various Concentrations and Temperatures, International Journal of Hydrogen Energy, vol. 32, pp. 359-364, 2007.

[33] Bockris, J. O’M., and Drazic, D. M., Electro-chemical Science, Taylor \& Francis, London, UK, 1972.

[34] Bard, A. J., and Faulkner, L. R., Electrochemical Methods-Fundamentals and Applications, 2nd ed., Wiley, New York, NY, 2001.

[35] Kincaid, D., and Cheney, W., Numerical Analysis Mathematics of Scientific Computing, Wadsworth, Belmont, CA, 1991.

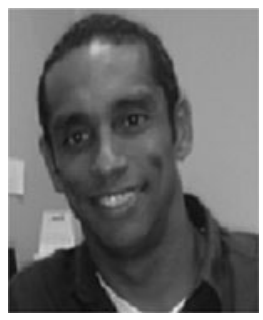

Lauber S. Martins is a senior lecturer in the Department of Mechanical and Aeronautical Engineering at the University of Pretoria, South Africa. His activities are concentrated on mathematical modeling and simulation of polymer electrolyte fuel cells and alkaline membrane fuel cells and their application. He received his $\mathrm{Ph} . \mathrm{D}$. in mechanical engineering from Florida State University, USA, in 2012. His research interest includes fuel cells, sustainable energy, thermodynamics, heat transfer, modeling, and simulation of power systems, optimization.

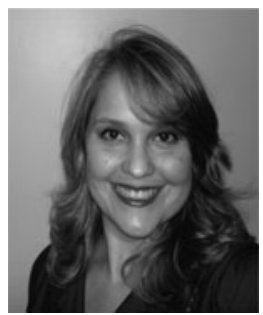

Elise M. Sommer is an assistant professor in the Department of Energy Engineering at Federal University of Santa Catarina. She received her doctoral degree in mechanical engineering from Universidade Federal do Paraná (UFPR), Brazil in 2012. She worked with mathematical modeling, experimental measurements, and thermodynamic optimization of alkaline membrane fuel cells during her doctoral and master's degrees. She received her master's degree from UFPR in 2009. She obtained her bachelor's 
degree in 2007 from Universidade Federal de Santa Catarina, Brazil, in chemical engineering. Her research interests include fuel cells and renewable energy technologies.

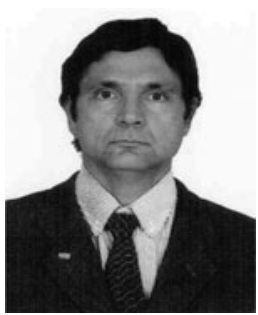

José V. C. Vargas is an associate professor in the Department of Mechanical Engineering at Federal University of Paraná, Curitiba, Brazil, and a visiting professor in the Department of Mechanical Engineering and the Center for Advanced Power Systems at Florida State University. His research interests include fuel cells, biofuels, alternative energy, constructal theory, and modeling, simulation, and optimization of complex integrated systems.

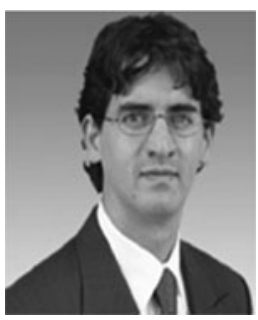

Juan C. Ordonez is an associate professor of mechanical engineering in the Department of Mechanical Engineering at Florida State University, USA. He is the principal investigator in the Thermal Modeling and Management Group at the Center for Advanced Power Systems (CAPS). His research interests comprise sustainable energy systems, thermodynamics, heat transfer, thermodynamic optimization, constructal theory, entropy generation minimization, computational heat transfer, thermal management and modeling of energy systems, fuel cells, heat exchanger design, cooling of electronics, microchannels, and photo-bioreactors.

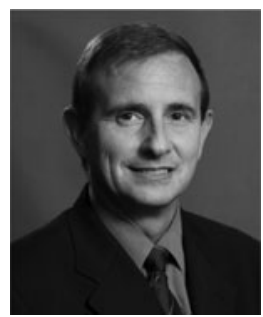

Josua P. Meyer is a professor, Chair of the School of Engineering, and Head of the Department of Mechanical and Aeronautical Engineering at the University of Pretoria, South Africa. He specializes in heat transfer, fluid mechanics, and thermodynamic aspects of heating, ventilation, and air conditioning. He is the author and co-author of more than 400 articles, conference papers, and patents, and has received various prestigious awards for his research. He is also a fellow or member of various professional institutes and societies and is regularly invited as a keynote speaker at local and international conferences. He is the recipient of various teaching awards such as Lecturer of the Year and has received three awards from the University of Pretoria as an exceptional achiever. In 2006, he was evaluated by the National Research Foundation (NRF) as an established researcher who enjoys considerable international recognition for the high quality and impact of his recent research outputs. He is an associate editor of Heat Transfer Engineering. 